\title{
Predicted pathogenic mutations in STAP1 are not associated with clinically defined familial hypercholesterolemia
}

\author{
Itziar Lamiquiz-Moneo ${ }^{\mathrm{a}, *}$, María Alejandra Restrepo-Córdoba ${ }^{\mathrm{b}}$, Rocío Mateo-Gallego ${ }^{\mathrm{a}, \mathrm{c}}$, \\ Ana María Bea ${ }^{a}$, María del Pino Alberiche-Ruano ${ }^{\mathrm{d}}$, Pablo García-Pavía ${ }^{\mathrm{b}, \mathrm{e}}$, Ana Cenarro ${ }^{\mathrm{a}}$, \\ Cesar Martín ${ }^{\mathrm{f}}$, Fernando Civeira ${ }^{\mathrm{a}, \mathrm{c}}$, Rosa María Sánchez-Hernández ${ }^{\mathrm{d}}$ \\ ${ }^{a}$ Lipid Unit, Hospital Universitario Miguel Servet, Instituto de Investigación Sanitaria Aragón (IIS Aragón), CIBER Cardiovascular (CIBERCV), Zaragoza, Spain \\ ${ }^{\mathrm{b}}$ Heart Failure and Inherited Cardiac Diseases Unit, Department of Cardiology, Hospital Universitario Puerta de Hierro, CIBER Cardiovascular (CIBERCV), Madrid, Spain \\ ${ }^{\mathrm{c}}$ Universidad de Zaragoza, Zaragoza, Spain \\ ${ }^{\mathrm{d}}$ Endocrinology Department, Hospital Universitario Insular de Gran Canaria, Instituto Universitario de Investigación Biomédica y de la Salud de la Universidad de Las \\ Palmas de Gran Canaria, Las Palmas, Spain \\ ${ }^{\mathrm{e}}$ Universidad Francisco de Vitoria (UFV), Pozuelo de Alarcon, Spain \\ ${ }^{\mathrm{f}}$ Instituto Biofisika (UPV/EHU, CSIC) and Departamento de Bioquímica, Universidad del País Vasco, Bilbao, Spain
}

\section{H I G H L I G H T S}

- STAP1 has been proposed as a candidate gene for FH with controversial results.

- Predicted pathogenic mutations in STAP1 in genetic negative FH were studied.

- These mutations in STAP1 did not cosegregate with hypercholesterolemia in families.

- STAP1 does not seem to play a major role in the etiology of FH.

\section{A R T I C L E I N F O}

\section{Keywords:}

Familial hypercholesterolemia

STAP1

Mutation-negative familial

hypercholesterolemia

Family cosegregation

\begin{abstract}
A B S T R A C T
Background and aims: Autosomal dominant familial hypercholesterolemia (FH) is caused by mutations in $L D L R$, $A P O B$ and PCSK9. Two new putative loci causing FH have been identified recently, the p.(Leu167del) mutation in $A P O E$ and new mutations in the signal transducing adaptor family member STAP1. We aimed at investigating the role of STAP1 mutations in the etiology of $\mathrm{FH}$.

Methods: We sequenced LDLR, APOB, PCSK9, LDLRAP1, APOE, LIPA and STAP1 with the LipidInCode platform in 400 unrelated subjects from Spain with a clinical diagnosis of FH. All subjects carrying rare predicted pathogenic variants in STAP1 gene, described as pathogenic by at least three bioinformatic analysis and having an allelic frequency lower than $1 \%$ in general population, were selected for family study. Available relatives were recruited, including both hypercholesterolemic and non-hypercholesterolemic family members.

Results: Sequencing analysis of STAP1 gene revealed seventeen rare variants, four of them being described as pathogenic by bioinformatic analysis. We studied the cosegregation with hypercholesterolemia of four rare predicted pathogenic variants, c.-60A > G, p.(Arg12His), p.(Glu97Asp), p.(Pro176Ser) in seven families. We did not observe any cosegregation between genotype and phenotype, even carriers of rare variants in STAP1 had lower LDL cholesterol levels than non-carriers.

Conclusions: This study analyzes the family cosegregation of four rare predicted pathogenic variants of STAP1, p. (Arg12His), p.(Glu97Asp), p.(Pro176Ser) and c.-60A > G, in seven families, showing absence of cosegregation in all of them. These results would suggest that STAP1 gene is not involved in hypercholesterolemia of these families.
\end{abstract}

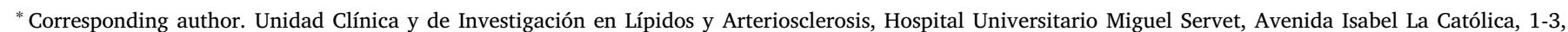
50009, Zaragoza, Spain.

E-mail address: itziarlamiquiz@gmail.com (I. Lamiquiz-Moneo). 


\section{Introduction}

Familial hypercholesterolemia (FH) is a genetic disorder characterized by very high plasma total cholesterol concentrations, due to increased low-density lipoprotein cholesterol (LDL cholesterol), with a high risk of premature coronary heart disease (CHD) [1]. Traditionally, FH has been described as a monogenic disease, with autosomal codominant transmission and an estimated prevalence of around 1:500 in the general population [2]. Recent studies have revealed that clinically defined FH is probably more common than previously reported, with a prevalence of 1:217 in the Copenhagen General Population study [3]. This prevalence is as high as 1:70 in some populations with a founder gene effect, such as Afrikaners from South Africa [4].

The clinical diagnosis of FH relies on a high level of LDL cholesterol in plasma, a family history of hypercholesterolemia, a personal and family history of premature CHD and signs of cholesterol deposition such as tendon xanthomas and premature arcus cornealis. These variables are often clinically scored by applying the Make Early Diagnosis to Prevent Early Death (MEDPED) criteria, the Dutch Lipid Clinic Network (DLCN) MEDPED modification, or the Simon Broome Register Group (SBRG) criteria [5].

FH is caused by mutations in $L D L R$, the gene coding for the LDL receptor; $A P O B$, encoding apolipoprotein B [6] and PCSK9, which encodes the enzyme proprotein convertase subtilisin/kexin type 9 [7]. One new putative locus causing $\mathrm{FH}$ has been identified: the $\mathrm{p}$. (Leu167del) mutation in APOE [8]. Besides, several mutations in the signal transducing adaptor family member STAP1 have been associated recently with FH etiopathology [9]. However, $20-40 \%$ of patients with possible familial hypercholesterolemia have not mutation in candidate genes [10], which could be due to the presence of new genes or mutations, previously not described, or the overlapping between $\mathrm{FH}$ with polygenic hypercholesterolemia. In this line, Talmud et al. [11] described 12 single nucleotide polymorphisms (SNPs), which could help discriminated $\mathrm{FH}$ from polygenic hypercholesterolemia.

STAP1 gene was associated with FH by Fouchier et al. [9] in 2014 using the exome sequencing and linkage analysis in one family with a clear FH phenotype. Besides, these authors sequenced the STAP1 gene in normolipemic patients and patients with $\mathrm{FH}$ without mutation in $L D L R, P C S K 9$ and $A P O B$ genes, and identified four new missense variants (p.(Glu97Asp), p.(Leu69Ser), p.(Ile71Thr) and p.(Asp207Asn) in STAP1, described as pathogenic by bioinformatic analysis, only present in patients clinically defined as FH. Fouchier et al. reported that patients carrying mutations in STAP1 have significantly lower values in their lipid profile than patients carrying mutations in $L D L R$, presenting a lipid phenotype very similar to carriers of $A P O B$ mutations.

The function of STAP1, which encodes a signal-transducing adaptor protein, is still unknown. STAP1 contains a domain with several tyrosine phosphorylation sites, which allows it to interact with the membrane or with membrane proteins [9]. Therefore, it seems that the involvement of STAP1 in cholesterol metabolism could be through interaction with membrane proteins. Subsequent studies have reported a subject clinically defined as $\mathrm{FH}$, with premature $\mathrm{CHD}$, carrying the $\mathrm{p}$. (Glu97Asp) mutation in STAP1 gene [12]. Another study with 255 patients with a personal and family history of premature CHD reported one patient carrier of a new mutation in STAP1 [13]. Consequently, the STAP1 gene has been included in many sequencing platforms for the genetic diagnosis of $\mathrm{FH}$, as a new candidate gene causing $\mathrm{FH}$.

We have analysed the STAP1 mutations found in FH subjects, to select those predicted to be pathogenic and to research the family cosegregation of four variants in STAP1, two of them not previously described, with the aim to investigate if these mutations in STAP1 could explain the phenotype of $\mathrm{FH}$.

\section{Materials and methods}

All genetic studies of FH performed with the LipidInCode platform
(GenInCode, Terrassa-Barcelona, Spain), including STAP1, were reviewed until December 2017 and those variants in STAP1 described as pathogenic by bioinformatic tools were selected. These predicted pathogenic variants were identified in FH index cases from the Lipid Clinics at Hospital Universitario Miguel Servet in Zaragoza, Hospital Universitario Puerta de Hierro in Madrid and Hospital Universitario Insular in Gran Canaria, all in Spain.

\subsection{Subjects}

Unrelated subjects above the age of 18 , with a clinical diagnosis of FH according of the DLCN criteria, untreated LDLc concentrations above 95th percentile of the Spanish population [14], triglycerides (TG) below $200 \mathrm{mg} / \mathrm{dL}$, and familial presentation (at least 1 first-degree relative with the same phenotype) were selected for this study. Exclusion criteria were secondary causes of hypercholesterolemia including: obesity (body mass index (BMI) $>30 \mathrm{~kg} / \mathrm{m}^{2}$ ), poorly controlled type 2 diabetes (HbA1c $>8 \%$ ), renal disease with glomerular filtration rate $<30 \mathrm{~mL} / \mathrm{min}$ and/or macroalbuminuria, liver disease (alanine transaminase $>3$ times upper normal limit), hypothyroidism (thyroid stimulating hormone $>6 \mathrm{mIU} / \mathrm{L}$ ), pregnancy, autoimmune diseases, and treatment with protease inhibitors. The assessment of cardiovascular risk factors, a personal and family history of cardiovascular disease, drugs intake affecting intestinal or lipid metabolism, and anthropometric measurements were performed in all participants.

Of all subjects carrying rare predicted pathogenic variants in STAP1 gene, reported pathogenic by at least three bioinformatic analysis and with an allelic frequency lower than $1 \%$ in general population, the available relatives were recruited, including both hypercholesterolemic and non-hypercholesterolemic family members.

\subsection{Lipid analysis}

Lipid and lipoprotein analyses were performed on EDTA plasma samples collected after at least $10 \mathrm{~h}$ overnight fast and without lipid lowering drugs in the previous 6 weeks. Total cholesterol and triglyceride (TG) levels were determined by standard enzymatic methods. HDL cholesterol was measured directly by an enzymatic reaction using cholesterol oxidase (UniCel DxC 800; Beckman Coulter, Inc, Brea, CA). LDL cholesterol was calculated by Friedewald's formula. All subjects signed an informed consent to a protocol previously approved by our local ethics committees. Lipoprotein(a) protein was determined by IMMAGE kinetic nephelometry (Beckman-Coulter, Inc) in all subjects from Hospital Universitario Miguel Servet in Zaragoza and Hospital Universitario Insular in Gran Canaria.

\subsection{Genetic analysis}

Whole blood genomic DNA was isolated using standard methods. Promoters, coding regions, and intron-exon boundaries of $L D L R$ (NM_000527.4), APOB (NM_000384.2), PCSK9 (NM_174936.3), APOE (NM_000041.3), STAP1 (NM_0121108.3), LDLRAP1 (NM_015627.2) and LIPA (NM_000235.3) genes were sequenced in the LipidInCode platform (GenInCode, Terrassa-Barcelona, Spain).

Data were analysed by the bioinformatic tool Gendicall (Gendiag.exe/FiC) using the BWA-mem alignment software with the gene reference grch37/hg19. The detection of variants was done with the SAMtools and Gendicall programs. The variants that presented between $15 \%$ and $85 \%$ of alternative or reference sequences were considering heterozygous. To evaluate the variants pathogenicity we used PolyPhen-2 [15], Mutation Taster [15] and PredictSNP [16]. The effect of variants in potential splicing sites was predicted with FruitFly [17]. To compare the frequency of identified variants in the general population, we have compiled the allele frequencies of the identified variants from the 1000 Genomes Project [18], ExAc Browser Data [19] and genome aggregation data base (gnomAD) [20]. 
For each proband, we calculated LDL score using the weighted sum of the risk allele of these SNPs: rs11220462 in ST3GAL4; rs1367117 in APOB; rs1564348 in SCL22A1; rs1800562 in HFE; rs2479409 in PCSK9; rs3757354 in MYLIP; rs429358 in APOE; rs4299376 in ABCG5/G8; rs629301 in CELSR2; rs6511720 in LDLR; rs7412 in APOE and rs8017377 in NYNRIN sequenced in the LipidInCode platform (GenInCode, Terrassa-Barcelona, Spain). The weights used were the corresponding per-allele (risk) beta coefficients reported by the Global Lipid Genetic Consortium (Supplemental Table 1). Calculated score above 0.73 indicated high probability of polygenic hypercholesterolemia according to the research carried out by Talmud et al. [11]. Besides, all proband families had determined two SNPs (rs10455872A $>$ G and rs3798220T $>$ C), which are closely related with the Lpa levels [21].

To define the pathogenicity classification of genomic variants according to the American College of Medical Genetics and Genomics (ACMG), we calculate the probability of observed cosegregation if not pathogenic variant in each family. We calculated a simple probability that the observed variant-affected status data occur by chance, rather than due to cosegregation. We assume that the proband(s) have that variant and full penetrance and that the allele is rare enough that all occurrences in the observed pedigrees are identical by descent, rather than the same variant entering the pedigree from more than one ancestor. Under a dominant model, this probability is $\mathrm{N}=(1 / 2)^{\mathrm{m}}$, where $\mathrm{m}$ is the number of meiosis of the variant of interest that are informative for cosegregation [22]. Proposed Cosegregation Evidence to Support Each ACMG-AMP Pathogenicity Evidence Level is described in the Supplemental Table 2.

\subsection{Statistical analysis}

Analyses were performed using statistical computing software $\mathrm{R}$ [23] version 3.5.0. The level of significance was set at $p<0.05$. The distribution of the variables was analysed by the Shapiro test. Quantitative variables with a normal distribution were expressed as mean \pm standard deviation and were analysed by the Student $t$-test. Variables with a skewed distribution were expressed as medians and interquartile ranges and were analysed with the Mann-Whitney $U$ test. Qualitative variables were expressed as percentages and were analysed by the Chisquared test.

\section{Results}

Supplemental Table 3 shows all variants identified by the Systematic NGS study of STAP1 until December 2017 with the LipidInCode platform. We selected four rare variants predicted as pathogenic, and they were studied in seven index cases and their relatives. One of the selected variants was located in the promoter region and three of them were located in the coding region of STAP1 gene, giving rise to missense variants.

Rare variants reported as pathogenic with bioinformatic analysis are shown in Table 1. The rare variant c. $-60 \mathrm{~A}>\mathrm{G}$ is located in the promoter region, its frequency in the general population is $0.17 \%$ and it has not been previously associated with $\mathrm{FH}$. We found three patients who carried this rare variant. In Fig. 1, the available family members are shown. Interestingly, proband of family 2 presented higher levels of total and LDL cholesterol than the others probands who carried the same rare variant (c.-60A > G). These higher levels could be explained because this proband is a carrier of the variant rs10455872A $>$ G in heterozygosity in LPA gene and presents higher level of LDL score. In Family 2, the proband brother is carrier of the c. $-60 \mathrm{~A}>\mathrm{G}$ variant, but he presents normal levels of total and LDL cholesterol. Same absence of cosegregation between phenotype and genotype is observed in Family 7 , as a proband brother, who is not carrier of the variant, shows high levels of total and LDL cholesterol. The proband daughter has normal levels in her lipid profile, although she is carrier of the rare variant.

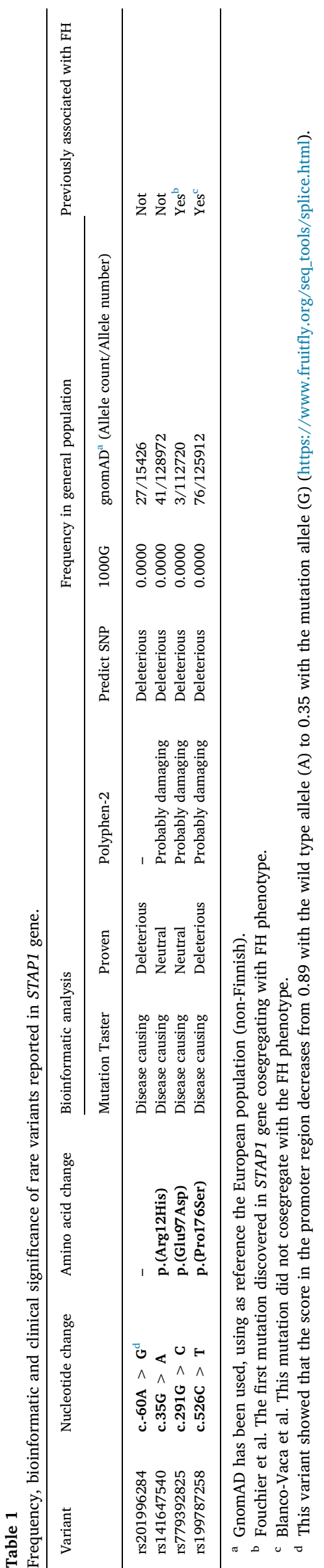




\section{Mutation c. $-60 A>G$}

Family 1

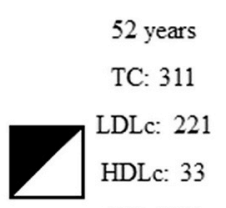

TG: 285

$\mathrm{E} 3 / 3$

LDL score: 0.868

Peripheral CVD

Family 7

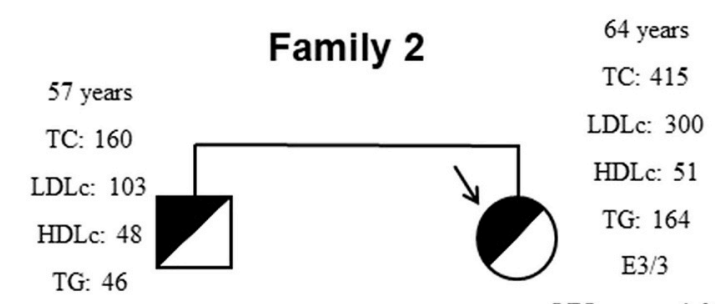

Witouth CVD
LDL score: 1.028

Peripheral CVD

rs1455872 (AG)
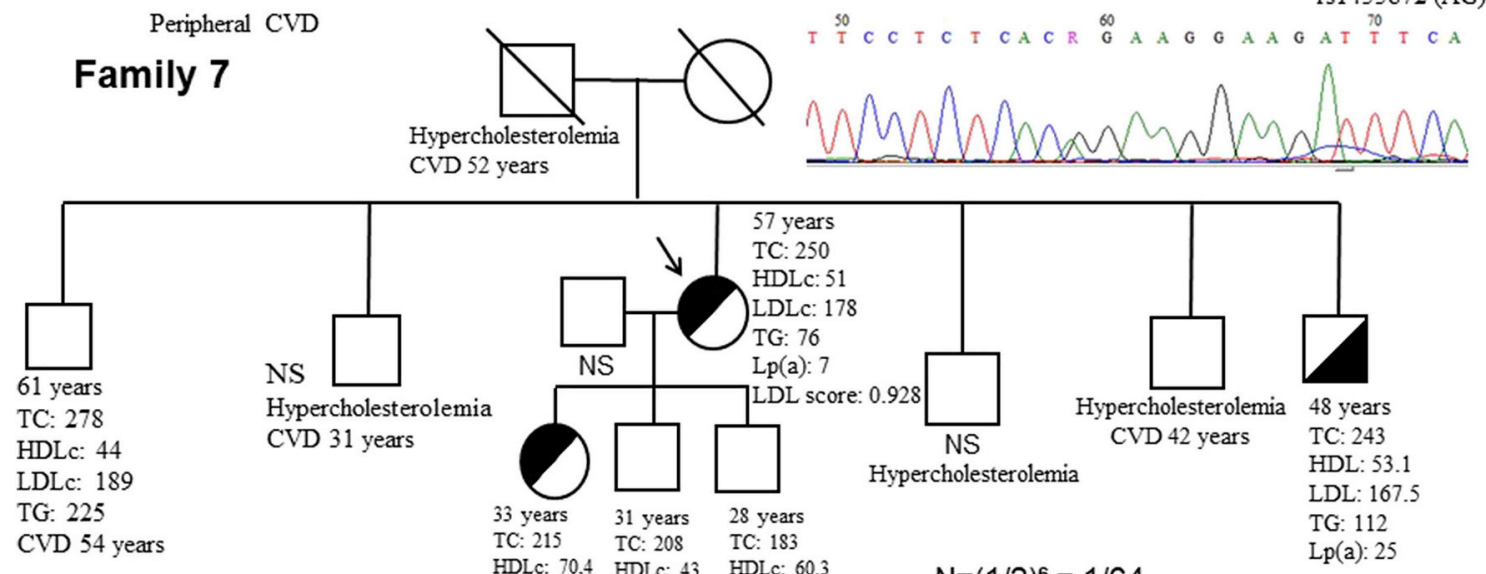

HDLC: 70,4 TC: 208 TC: 183

LDLc: 133 LDLc: 142 LDLc: 110,3

$\begin{array}{lll}\text { TG: } 56 & \text { TG: } 117 & \text { TG: } 62\end{array}$

$\begin{array}{lll}\text { Lp(a): } 39 & \text { Lp(a): }<3 & \text { Lp(a) }<3\end{array}$

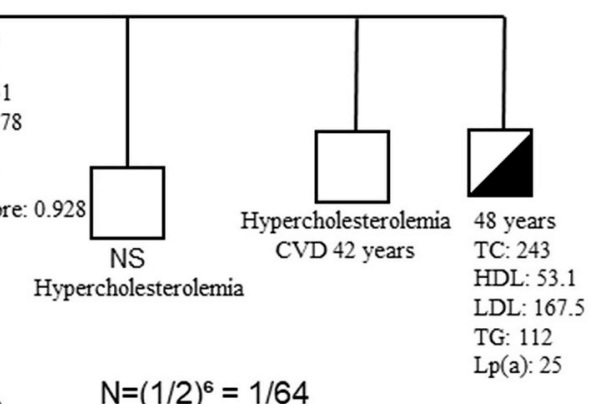

ACMG strong evidence

Fig. 1. Families carrying the c.-60A > G mutation in STAP1 gene.

NS: Not studied; TC: Total cholesterol; LDLc: Low Density Lipoprotein cholesterol; HDLc: High Density Lipoprotein cholesterol; TG: Triglyceride; CVD: Cardiovascular Disease; Lp(a): Lipoprotein a; ACMG: American College of Medical Genetics and Genomics.

Besides, according to the ACMG guideline, Family 7 showed strong evidence of lack of segregation phenotype-genotype. All family members in Family 7 showed normal levels of Lp(a).

The rare variant c.35G > A is located in exon 1 and is predicted to cause a substitution of arginine by histidine at amino acid 12 of STAP1, p.(Arg12His). This amino acid change has not been previously described in FH patients, although it has been described as deleterious by bioinformatic analysis. Besides, its frequency in the general population is extremely low, less than $0.1 \%$ (Table 1 ). We found one patient with this rare variant, who presented high levels of total and LDL cholesterol. However, his daughter presented normal levels in her lipid profile, although she was also carrier of the same rare variant (Fig. 2).

The rare variant c.291G $>\mathrm{C}$ is located in exon 3 and is predicted to cause a substitution of glutamic acid by aspartic acid at amino acid 97 in STAP1 protein, p.(Glu97Asp). This rare variant has been previously described in FH patients by Fouchier et al. [9] and it has been described as pathogenic by bioinformatic analysis. The proband and his daughter in Family 3 are carriers of the variant; the daughter presents normal levels in her lipid profile (Fig. 3).

The rare variant c.526C $>\mathrm{T}$ is located in exon 5 and is predicted to cause a substitution of proline by arginine at amino acid 176, p. (Pro176Ser). This variant has been previously described by Blanco-Vaca et al. [24], being incompletely associated with FH phenotype. We have found two unrelated probands carriers of this rare variant. Both probands presented high levels of LDL score, higher than 0.73 , calculated from 12 SNPs indicated by Talmud et al. [11]. Proband's Family 6, who had higher LDL score and E4/4 APOE genotype, showed higher levels of total and LDL cholesterol than proband Family 5, although both were carriers of the same rare variant in STAP1. As it is shown in Fig. 4, all available family members in Family 5 are carriers of this variant, but only the proband presented high levels of total and LDL cholesterol. Interestingly, proband Family 5 and her sons had high levels of Lipoprotein (a), although only the proband presented hypercholesterolemia. The same absence of cosegregation between phenotype and genotype was found in Family 6, in which the proband and her sons are carriers of this rare variant, although the daughter showed normal levels of total and LDL cholesterol. All family members in Family 6 showed normal levels of Lp(a). Besides, both families showed strong evidence of lack of cosegregation phenotype-genotype, according to the ACMG guidelines.

Table 2 shows biochemical characteristics of carriers and non-carriers of rare variants identified in STAP1 gene. Carriers of rare variants presented significantly higher levels of HDL cholesterol than non-carriers $(p=0.019)$, with no further differences in their lipid profile, even the carriers present lower levels of LDL cholesterol than non-carriers. Due to the allele frequency of the variant in the promoter region (c.$60 \mathrm{~A}>\mathrm{G}$ ) in the general population of $0.17 \%$, which would be above the cut-off recommended for filtering of variants causing Mendelian diseases [25], we reanalyzed the biochemical characteristics of carriers and non-carriers of rare variants identified in STAP1 gene without carriers of promoter variant. Carriers of missense rare variants (p.(Arg12His), p.(Glu97Asp) and p.(Pro176Ser)) in STAP1 presented significantly lower age and higher levels of HDL cholesterol than noncarriers of missense rare variants $(p=0.041$ and $p=0.007$, respectively), with no further differences in their lipid profile, showing that even the carriers present lower levels of LDL cholesterol than noncarriers (Supplemental Table 4).

\section{Discussion}

Our results do not confirm a major role of STAP1 in the etiology of 


\section{Mutation c.35G $>$ A; p.(Arg12His)}

\section{Family 4}

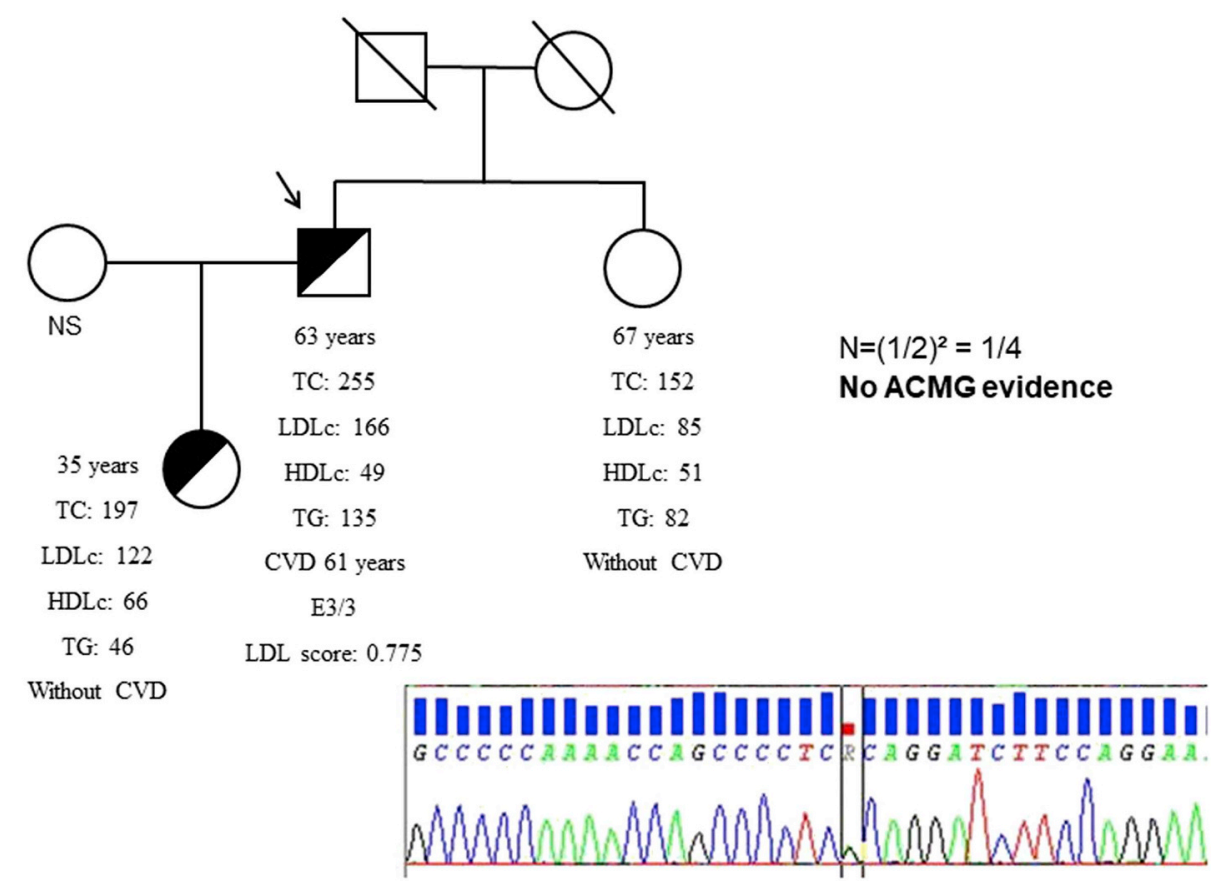

Fig. 2. Family carrying the c. $35 \mathrm{G}>\mathrm{A}$, p.(Arg12His) mutation in STAP1 gene.

NS: Not studied; TC: Total cholesterol; LDLc: Low Density Lipoprotein cholesterol; HDLc: High Density Lipoprotein cholesterol; TG: Triglyceride; CVD: Cardiovascular Disease; Lp(a): Lipoprotein a; ACMG: American College of Medical Genetics and Genomics.

FH. This study analyzes the cosegregation of four predicted pathogenic rare variants in seven families, showing the absence of correlation between genotype and phenotype. The four rare variants reported in this study have been predicted as pathogenic by at least three bioinformatic analysis; three of them produce an amino acid change, p.(Arg12His), p. (Glu97Asp), p.(Pro176Ser) and one of them is located in the promoter region, c.-60A > G. Only two of these four predicted pathogenic rare variants had been previously described, one of them associated with $\mathrm{FH}$ [9] and the other one has been described as incompletely associated with FH [24].

The rare variant p.(Glu97Asp) in STAP1 had been described associated with FH by Fouchier et al. [9] in 2014 from the linkage analysis combined with exome sequencing in an FH family. After studying a large family with 27 family members, the authors demonstrated a good correlation between genotype and phenotype, but there were some inconsistencies in the family cosegregation: they reported four affected family members with LDL cholesterol above 95th percentile, who did not carry this rare variant and one non-affected family member, who was carrier of this variant. Despite several studies have included the sequencing of STAP1 in FH patients or patients with CVD in the last years, the results have not been conclusive. Corral et al. [26] sequenced 69 subjects with clinical diagnosis of FH, with more than 6 points DLCN and they did not identify any mutation in STAP1. In the same line, Pirillo et al. [27] sequenced the candidate FH genes in 1592 unrelated patients with clinical diagnosis of $\mathrm{FH}$, finding 1076 carriers of 216 mutations in LDLR, APOB, PCSK9, LDLRAP1 and APOE, but no STAP1 carriers. Amor-Salamanca et al. [12] sequenced LDLR, APOB, PCSK9, APOE, STAP1, LDLRAP1 and LIPA genes in 821 patients with premature CVD, reporting only one patient, who was carrier of the same mutation described by Fouchier et al. [9]. Although they did not report the cholesterol levels of the STAP1 carrier, they showed that the proband daughter, who was carrier of the same mutation, presented normal levels of total and LDL cholesterol $(166 \mathrm{mg} / \mathrm{dL}$ and $99 \mathrm{mg} / \mathrm{dL}$, respectively). Blanco-Vaca et al. [24] reported one predicted pathogenic rare variant with incomplete association with $\mathrm{FH}$. They studied one family with three hypercholesterolemic siblings, who were carriers of the rare variant p.(Pro176Ser) in STAP1 gene. However, not all siblings showed high cholesterol levels and none of them presented LDL cholesterol concentrations compatible with the classical FH phenotype. Besides, the proband son, who was carrier of the same variant, presented normal total and LDL cholesterol levels $(212 \mathrm{mg} / \mathrm{dL}$ and $121 \mathrm{mg} / \mathrm{dL}$, respectively). Finally, Brænne et al. [13] sequenced the candidate FH genes in 255 subjects with premature CVD with at least one sibling with CVD before 70 years, reporting only one variant in STAP1 gene, p. (Thr47Ala). This rare variant had not been previously described and the authors have classified it as pathogenic, although both carrier siblings presented different concentrations of LDL cholesterol, one of them below the 95th percentile.

Several genome wide association studies (GWAS) have been performed with the aim of searching for new genes involved in cholesterol metabolism [28-30]. However, none of these studies has demonstrated an association between genetic variants in STAP1 and cholesterol levels. To our knowledge, the unique association with STAP1 variants located has been described with Parkinson disease by Fung et al. [31]. The authors genotyped 276 unrelated patients with Parkinson disease and 276 unrelated controls, reporting the variant rs2242330, located in an intronic region, which was significantly associated with the development of Parkinson disease.

Several exome sequencing studies had the goal of searching for new genes that could explain the etiology of FH without mutations in candidate genes. However, except that of Fouchier et a.1 [9], there are no other studies reporting mutations in STAP1 as cause of FH. Exome sequencing studies allowed to discover new mutations in $L D L R, A P O B$ and PCSK9. For example, Futema et al. [32] sequenced the exome of 125 


\section{Mutation c.291G>C; p.(Glu97Asp)}

Family 3

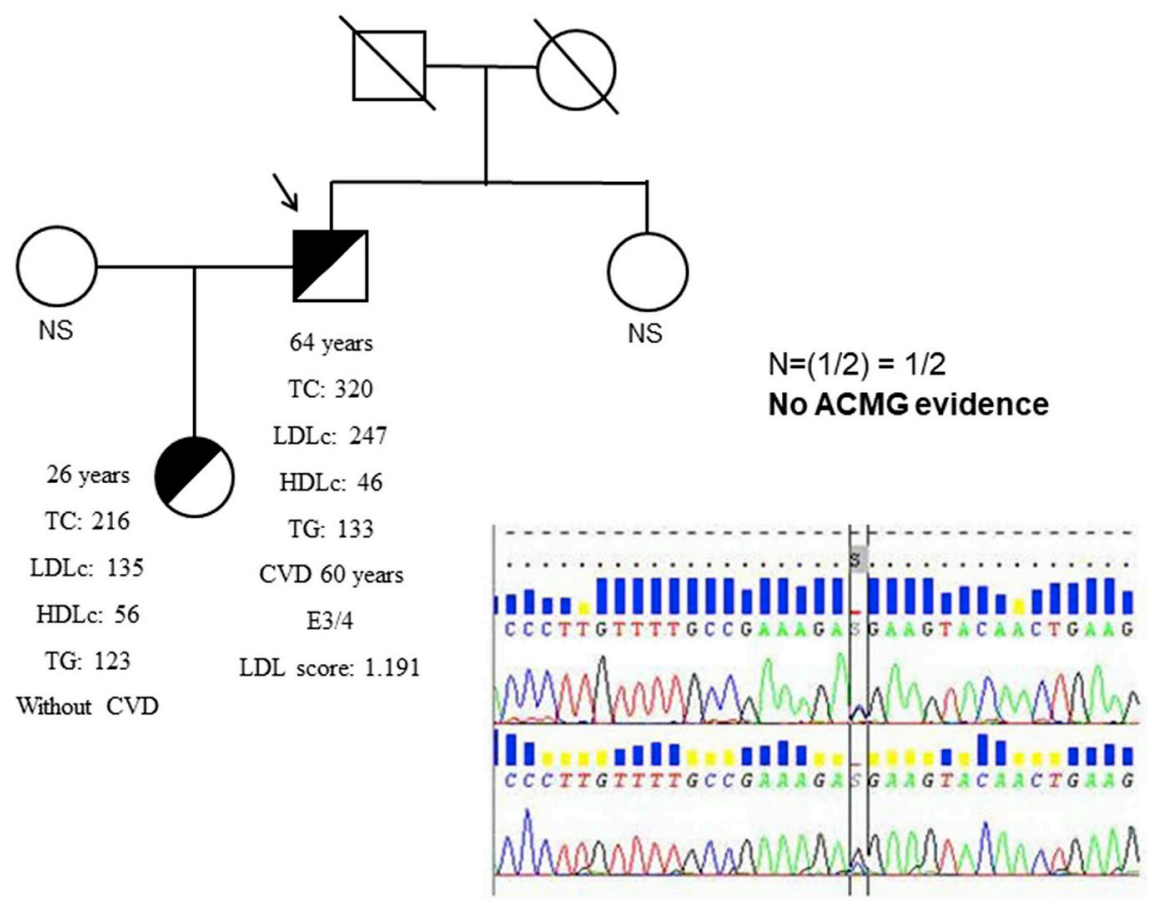

Fig. 3. Family carrying the c. $291 \mathrm{G}>$ C, p.(Glu97Asp) mutation in STAP1 gene.

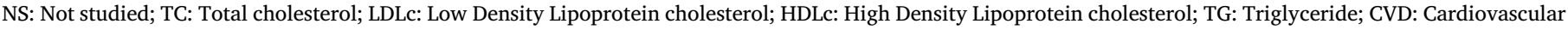
Disease; Lp(a): Lipoprotein a; ACMG: American College of Medical Genetics and Genomics.

definite FH patients, without mutation in $L D L R, A P O B$ neither PCSK9 genes. They reported 23 new mutations in $L D L R$ and two new mutations in $A P O B$, but no mutation in STAP1. Brænne et al. [33], using the exome sequencing analysis in three $\mathrm{FH}$ affected family members, discovered one new mutation in the $L D L R$ gene. In the same line, Han et al. [34] used exome sequencing to look for new mutations in $L D L R, A P O B$

\section{Mutation c.526C $>$ T; p.(Pro176Ser)}
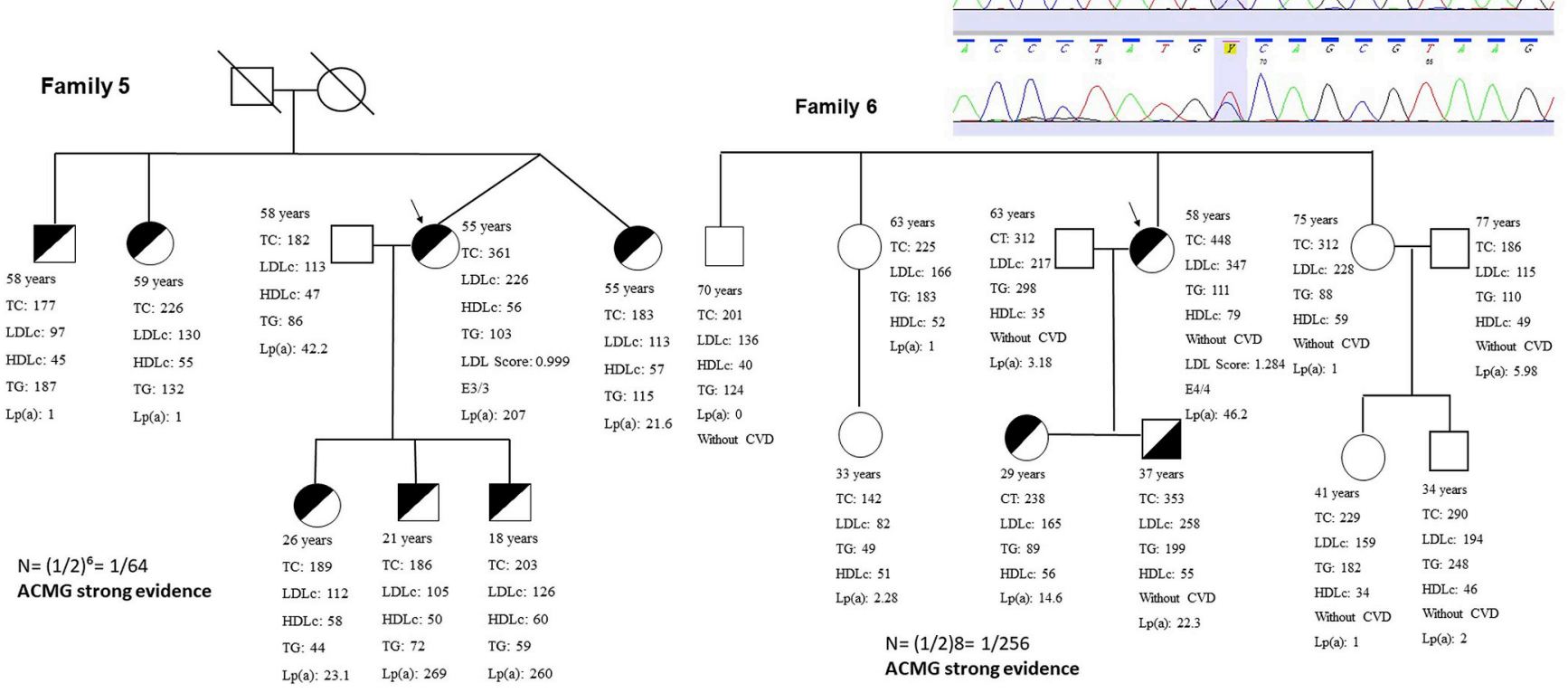

Fig. 4. Family carrying the c.526C > T, p.(Pro176Ser) mutation in STAP1 gene.

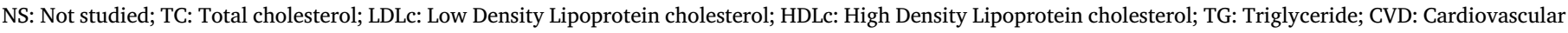
Disease; Lp(a): Lipoprotein a; ACMG: American College of Medical Genetics and Genomics. 
Table 2

Biochemical characteristics of carriers and non-carriers of pathogenic rare variants identified in STAP1 gene.

\begin{tabular}{|c|c|c|c|}
\hline & Carriers of rare variants in STAP1 $(\mathrm{N}=20)$ & Non carries of rare variants in STAP1 $(\mathrm{N}=14)$ & $p$ \\
\hline Age, years & $45.6 \pm 16.0$ & $53.9 \pm 17.9$ & 0.189 \\
\hline Men, n (\%) & $7(35.0 \%)$ & $9(64.3 \%)$ & 0.061 \\
\hline Total cholesterol, mg/dL & $226(193-280)$ & $208(183-278)$ & 0.443 \\
\hline LDL cholesterol, mg/dL & $135(118-200)$ & $142(113-189)$ & 0.716 \\
\hline HDL cholesterol, mg/dL & $56.0(49.5-67.5)$ & $49.0(43.0-52.0)$ & 0.019 \\
\hline Triglycerides, mg/dL & $111(65.5-132)$ & $117(86.0-183)$ & 0.357 \\
\hline
\end{tabular}

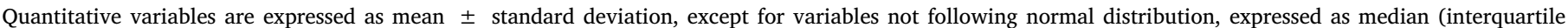
range). Qualitative variables are expressed as $\mathrm{n}(\%)$. The $p$ value was calculated by Student's $t$-test, Mann-Whitney $\mathrm{U}$ and Chi - square as appropriate.

and PCSK9 genes, not reporting any variant in STAP1 gene. Jiang et al. [35] used targeted exome sequencing in young patients with severe hypercholesterolemia and they discover 27 mutations in $L D L R$, including 3 novel mutations in $L D L R$ gene. Iacocca et al. [36] used targeted next-generation sequencing to discover copy number variations in APOB, PCSK9, LDLRAP1, APOE, STAP1, LIPA, and ABCG5/8 genes. The authors sequenced 704 patients with $\mathrm{FH}$ and they did not find any copy number variation in these candidate genes.

Our study has some limitations: some families had few available members, especially in Family 3, that carried the mutation p. (Glu97Asp), which could be an important limitation. However, despite that, the absence of relation between phenotype and genotype was clear in this family. Theses pathogenic mutations need a functional analysis to be considered totally pathogenic. Another possible limitation could be the limited number of rare variants studied for the family analysis. Nevertheless, we concentrated on those variants predicted to be pathogenic. If these variants have not reported any relationship with the FH phenotype, then those variables with dubious pathogenicity and more frequently found in the population, probably would have not explained the pathogenesis of FH. Finally, familial cosegregation analysis provides initial evidence of a major effect on a particular phenotypic trait with a certain locus when the trait is under the control of a single gene. It is well established that some clinically defined FH are in fact polygenic diseases [11,37]. If STAP1 genetic variation contributes to these polygenic FH cannot be excluded from our study.

\subsection{Conclusions}

Our study including the predicted pathogenic mutations in STAP1 does not confirm the role of STAP1 in FH. This study analyzes the cosegregation of four predicted pathogenic rare variants, three of them producing an amino acid change, p.(Arg12His), p.(Glu97Asp), p. (Pro176Ser) and one of them, located in the promoter region, c.$60 \mathrm{~A}>\mathrm{G}$, in seven families, showing an absence of correlation between genotype and phenotype.

\section{Financial support}

This study was supported by B14-17R grant from Gobierno de Aragón and grants PI18/01777, and CIBERCV from the Spanish Ministry of Economy and Competitiveness, co-financed by Instituto de Salud Carlos III and the European Regional Development Fund (ERDF) of the European Union "A way to make Europe".

\section{Declaration of competing interest}

The authors declared they do not have anything to disclose regarding conflict of interest with respect to this manuscript.

\section{Acknowledgments}

The authors thank Elkie Suñén for her English editorial assistance. All authors have read and approved the final manuscript.

\section{Appendix A. Supplementary data}

Supplementary data to this article can be found online at https:// doi.org/10.1016/j.atherosclerosis.2019.11.025.

\section{References}

[1] F. Civeira, International panel on management of familial hypercholesterolemia, guidelines for the diagnosis and management of heterozygous familial hypercholesterolemia, Atherosclerosis 173 (2004) 55-68, https://doi.org/10.1016/j. atherosclerosis.2003.11.010.

[2] J.L. Goldstein, M.S. Brown, The LDL receptor, Arterioscler. Thromb. Vasc. Biol. 29 (2009) 431-438, https://doi.org/10.1161/ATVBAHA.108.179564.

[3] M. Benn, G.F. Watts, A. Tybjærg-Hansen, B.G. Nordestgaard, Mutations causative of familial hypercholesterolaemia: screening of 98098 individuals from the Copenhagen General Population Study estimated a prevalence of 1 in 217, Eur. Heart J. 37 (2016) 1384-1394, https://doi.org/10.1093/eurheartj/ehw028.

[4] M.J. Kotze, W.J. De Villiers, K. Steyn, J.A. Kriek, A.D. Marais, E. Langenhoven, J.S. Herbert, J.F. Graadt Van Roggen, D.R. Van der Westhuyzen, G.A. Coetzee, Phenotypic variation among familial hypercholesterolemics heterozygous for either one of two Afrikaner founder LDL receptor mutations, Arterioscler. Thromb. 13 (1993) 1460-1468.

[5] M.A. Austin, C.M. Hutter, R.L. Zimmern, S.E. Humphries, Genetic causes of monogenic heterozygous familial hypercholesterolemia: a HuGE prevalence review, Am. J. Epidemiol. 160 (2004) 407-420, https://doi.org/10.1093/aje/kwh236.

[6] A. Saltijeral, L. Pérez de Isla, R. Alonso, O. Muñiz, J.L. Díaz-Díaz, F. Fuentes, N. Mata, R. de Andrés, G. Díaz-Soto, J. Pastor, J.M. Pinilla, D. Zambón, X. Pinto, L. Badimón, P. Mata, SAFEHEART investigators, attainment of LDL cholesterol treatment goals in children and adolescents with familial hypercholesterolemia. The SAFEHEART follow-up registry, Rev. Esp. Cardiol. 70 (2017) 444-450, https://doi. org/10.1016/j.rec.2016.10.010.

[7] S.C. Hunt, P.N. Hopkins, K. Bulka, M.T. McDermott, T.L. Thorne, B.B. Wardell, B.R. Bowen, D.G. Ballinger, M.H. Skolnick, M.E. Samuels, Genetic localization to chromosome 1p32 of the third locus for familial hypercholesterolemia in a Utah kindred, Arterioscler. Thromb. Vasc. Biol. 20 (2000) 1089-1093.

[8] A. Cenarro, A. Etxebarria, I. de Castro-Orós, M. Stef, A.M. Bea, L. Palacios, R. MateoGallego, A. Benito-Vicente, H. Ostolaza, T. Tejedor, C. Martín, F. Civeira, The p.Leu167del Mutation in APOE Gene Causes Autosomal Dominant Hypercholesterolemia by Down-regulation of LDL Receptor Expression in Hepatocytes, J. Clin. Endocrinol. Metab. 101 (2016) 2113-2121, https://doi.org/ $10.1210 /$ jc. 2015-3874.

[9] S.W. Fouchier, G.M. Dallinga-Thie, J.C.M. Meijers, N. Zelcer, J.J.P. Kastelein, J.C. Defesche, G.K. Hovingh, Mutations in STAP1 are associated with autosomal dominant hypercholesterolemia, Circ. Res. 115 (2014) 552-555, https://doi.org/ 10.1161/CIRCRESAHA.115.304660.

[10] L. Palacios, L. Grandoso, N. Cuevas, E. Olano-Martín, A. Martinez, D. Tejedor, M. Stef, Molecular characterization of familial hypercholesterolemia in Spain, Atherosclerosis 221 (2012) 137-142, https://doi.org/10.1016/j.atherosclerosis. 2011.12.021.

[11] P.J. Talmud, S. Shah, R. Whittall, M. Futema, P. Howard, J.A. Cooper, S.C. Harrison, K. Li, F. Drenos, F. Karpe, H.A.W. Neil, O.S. Descamps, C. Langenberg, N. Lench, M. Kivimaki, J. Whittaker, A.D. Hingorani, M. Kumari, S.E. Humphries, Use of lowdensity lipoprotein cholesterol gene score to distinguish patients with polygenic and monogenic familial hypercholesterolaemia: a case-control study, Lancet 381 (2013) 1293-1301, https://doi.org/10.1016/S0140-6736(12)62127-8.

[12] A. Amor-Salamanca, S. Castillo, E. Gonzalez-Vioque, F. Dominguez, L. Quintana, C. Lluís-Ganella, J.M. Escudier, J. Ortega, E. Lara-Pezzi, L. Alonso-Pulpon, P. Garcia-Pavia, Genetically confirmed familial hypercholesterolemia in patients with acute coronary syndrome, J. Am. Coll. Cardiol. 70 (2017) 1732-1740, https:// doi.org/10.1016/j.jacc.2017.08.009.

[13] I. Brænne, M. Kleinecke, B. Reiz, E. Graf, T. Strom, T. Wieland, M. Fischer, T. Kessler, C. Hengstenberg, T. Meitinger, J. Erdmann, H. Schunkert, Systematic analysis of variants related to familial hypercholesterolemia in families with premature myocardial infarction, Eur. J. Hum. Genet. 24 (2016) 191-197, https://doi. org/10.1038/ejhg.2015.100.

[14] J.A. Gómez-Gerique, J.A. Gutiérrez-Fuentes, M.T. Montoya, A. Porres, A. Rueda, A. Avellaneda, M.A. Rubio, [Lipid profile of the Spanish population: the DRECE 
(diet and risk of cardiovascular disease in Spain) study. DRECE study group], Med. Clínica 113 (1999) 730-735.

[15] I.A. Adzhubei, S. Schmidt, L. Peshkin, V.E. Ramensky, A. Gerasimova, P. Bork, A.S. Kondrashov, S.R. Sunyaev, A method and server for predicting damaging missense mutations, Nat. Methods 7 (2010) 248-249, https://doi.org/10.1038/ nmeth0410-248.

[16] Y. Choi, G.E. Sims, S. Murphy, J.R. Miller, A.P. Chan, Predicting the functional effect of amino acid substitutions and indels, PLoS One 7 (2012) e46688, , https:// doi.org/10.1371/journal.pone.0046688.

[17] J. Bendl, M. Musil, J. Štourač, J. Zendulka, J. Damborský, J. Brezovský, PredictSNP2: a unified platform for accurately evaluating SNP effects by exploiting the different characteristics of variants in distinct genomic regions, PLoS Comput. Biol. 12 (2016) e1004962, , https://doi.org/10.1371/journal.pcbi.1004962.

[18] 1000 Genomes Project Consortium, G.R. Abecasis, A. Auton, L.D. Brooks, M.A. DePristo, R.M. Durbin, R.E. Handsaker, H.M. Kang, G.T. Marth, G.A. McVean, An integrated map of genetic variation from 1,092 human genomes, Nature 491 (2012) 56-65, https://doi.org/10.1038/nature11632.

[19] M. Lek, K.J. Karczewski, E.V. Minikel, K.E. Samocha, E. Banks, T. Fennell, A.H. O'Donnell-Luria, J.S. Ware, A.J. Hill, B.B. Cummings, T. Tukiainen, D.P. Birnbaum, J.A. Kosmicki, L.E. Duncan, K. Estrada, F. Zhao, J. Zou, E. PierceHoffman, J. Berghout, D.N. Cooper, N. Deflaux, M. DePristo, R. Do, J. Flannick, M. Fromer, L. Gauthier, J. Goldstein, N. Gupta, D. Howrigan, A. Kiezun, M.I. Kurki, A.L. Moonshine, P. Natarajan, L. Orozco, G.M. Peloso, R. Poplin, M.A. Rivas, V. Ruano-Rubio, S.A. Rose, D.M. Ruderfer, K. Shakir, P.D. Stenson, C. Stevens, B.P. Thomas, G. Tiao, M.T. Tusie-Luna, B. Weisburd, H.-H. Won, D. Yu, D.M. Altshuler, D. Ardissino, M. Boehnke, J. Danesh, S. Donnelly, R. Elosua, J.C. Florez, S.B. Gabriel, G. Getz, S.J. Glatt, C.M. Hultman, S. Kathiresan, M. Laakso, S. McCarroll, M.I. McCarthy, D. McGovern, R. McPherson, B.M. Neale, A. Palotie, S.M. Purcell, D. Saleheen, J.M. Scharf, P. Sklar, P.F. Sullivan, J. Tuomilehto, M.T. Tsuang, H.C. Watkins, J.G. Wilson, M.J. Daly, D.G. MacArthur, Exome Aggregation Consortium, Analysis of protein-coding genetic variation in 60,706 humans, Nature 536 (2016) 285-291, https://doi.org/10.1038/nature19057.

[20] K.J. Karczewski, L.C. Francioli, G. Tiao, B.B. Cummings, J. Alföldi, Q. Wang, R.L. Collins, K.M. Laricchia, A. Ganna, D.P. Birnbaum, L.D. Gauthier, H. Brand, M. Solomonson, N.A. Watts, D. Rhodes, M. Singer-Berk, E.M. England, E.G. Seaby, J.A. Kosmicki, R.K. Walters, K. Tashman, Y. Farjoun, E. Banks, T. Poterba, A. Wang, C. Seed, N. Whiffin, J.X. Chong, K.E. Samocha, E. Pierce-Hoffman, Z. Zappala, A.H. O'Donnell-Luria, E.V. Minikel, B. Weisburd, M. Lek, J.S. Ware, C. Vittal, I.M. Armean, L. Bergelson, K. Cibulskis, K.M. Connolly, M. Covarrubias, S. Donnelly, S. Ferriera, S. Gabriel, J. Gentry, N. Gupta, T. Jeandet, D. Kaplan, C. Llanwarne, R. Munshi, S. Novod, N. Petrillo, D. Roazen, V. Ruano-Rubio, A. Saltzman, M. Schleicher, J. Soto, K. Tibbetts, C. Tolonen, G. Wade, M.E. Talkowski, The Genome Aggregation Database Consortium, B.M. Neale, M.J. Daly, D.G. MacArthur, Variation across 141,456 human exomes and genomes reveals the spectrum of loss-of-function intolerance across human protein-coding genes, Genomics (2019), https://doi.org/10.1101/531210.

[21] S. Zewinger, M.E. Kleber, V. Tragante, R.O. McCubrey, A.F. Schmidt, K. Direk, U. Laufs, C. Werner, W. Koenig, D. Rothenbacher, U. Mons, L.P. Breitling, H. Brenner, R.T. Jennings, I. Petrakis, S. Triem, M. Klug, A. Filips, S. Blankenberg, C. Waldeyer, C. Sinning, R.B. Schnabel, K.J. Lackner, E. Vlachopoulou, O. Nygård, G.F.T. Svingen, E.R. Pedersen, G.S. Tell, J. Sinisalo, M.S. Nieminen, R. Laaksonen, S. Trompet, R.A.J. Smit, N. Sattar, J.W. Jukema, H.V. Groesdonk, G. Delgado, T. Stojakovic, A.P. Pilbrow, V.A. Cameron, A.M. Richards, R.N. Doughty, Y. Gong, R. Cooper-DeHoff, J. Johnson, M. Scholz, F. Beutner, J. Thiery, J.G. Smith, R.O. Vilmundarson, R. McPherson, A.F.R. Stewart, S. Cresci, P.A. Lenzini, J.A. Spertus, O. Olivieri, D. Girelli, N.I. Martinelli, A. Leiherer, C.H. Saely, H. Drexel, A. Mündlein, P.S. Braund, C.P. Nelson, N.J. Samani, D. Kofink, I.E. Hoefer, G. Pasterkamp, A.A. Quyyumi, Y.-A. Ko, J.A. Hartiala, H. Allayee, W.H.W. Tang, S.L. Hazen, N. Eriksson, C. Held, E. Hagström, L. Wallentin, A. Åkerblom, A. Siegbahn, I. Karp, C. Labos, L. Pilote, J.C. Engert, J.M. Brophy, G. Thanassoulis, P. Bogaty, W. Szczeklik, M. Kaczor, M. Sanak, S.S. Virani, C.M. Ballantyne, V.-V. Lee, E. Boerwinkle, M.V. Holmes, B.D. Horne, A. Hingorani, F.W. Asselbergs, R.S. Patel, GENIUS-CHD consortium, B.K. Krämer, H. Scharnagl, D. Fliser, W. März, T. Speer, Relations between lipoprotein(a) concentrations, LPA genetic variants, and the risk of mortality in patients with established coronary heart disease: a molecular and genetic association study, Lancet Diabetes Endocrinol 5 (2017) 534-543, https://doi.org/10.1016/S2213-8587(17)30096-7.

[22] G.P. Jarvik, B.L. Browning, Consideration of cosegregation in the pathogenicity classification of genomic variants, Am. J. Hum. Genet. 98 (2016) 1077-1081, https://doi.org/10.1016/j.ajhg.2016.04.003.

[23] R.C. Team, R Foundation for Statistical Computing; Vienna, Austria, (2014) R: A Language and Environment for Statistical Computing. (2018) 2013.

[24] F. Blanco-Vaca, J.M. Martín-Campos, A. Pérez, P. Fuentes-Prior, A rare STAP1 mutation incompletely associated with familial hypercholesterolemia, Clin. Chim. Acta 487 (2018) 270-274, https://doi.org/10.1016/j.cca.2018.10.014.

[25] M.J. Bamshad, S.B. Ng, A.W. Bigham, H.K. Tabor, M.J. Emond, D.A. Nickerson, $\mathrm{J}$. Shendure, Exome sequencing as a tool for Mendelian disease gene discovery, Nat. Rev. Genet. 12 (2011) 745-755, https://doi.org/10.1038/nrg3031.

[26] P. Corral, A.S. Geller, E.Y. Polisecki, G.I. Lopez, V.G. Bañares, L. Cacciagiu, G. Berg, R.A. Hegele, E.J. Schaefer, L.E. Schreier, Unusual genetic variants associated with hypercholesterolemia in Argentina, Atherosclerosis 277 (2018) 256-261, https:// doi.org/10.1016/j.atherosclerosis.2018.06.009.

[27] A. Pirillo, K. Garlaschelli, M. Arca, M. Averna, S. Bertolini, S. Calandra, P. Tarugi, A.L. CatapanoLIPIGEN Group, Spectrum of mutations in Italian patients with familial hypercholesterolemia: new results from the LIPIGEN study, Atherosclerosis Suppl. 29 (2017) 17-24, https://doi.org/10.1016/j.atherosclerosissup.2017.07.
002.

[28] C.J. Willer, E.M. Schmidt, S. Sengupta, G.M. Peloso, S. Gustafsson, S. Kanoni, A. Ganna, J. Chen, M.L. Buchkovich, S. Mora, J.S. Beckmann, J.L. Bragg-Gresham, H.-Y. Chang, A. Demirkan, H.M. Den Hertog, R. Do, L.A. Donnelly, G.B. Ehret, T. Esko, M.F. Feitosa, T. Ferreira, K. Fischer, P. Fontanillas, R.M. Fraser, D.F. Freitag, D. Gurdasani, K. Heikkilä, E. Hyppönen, A. Isaacs, A.U. Jackson, Å. Johansson, T. Johnson, M. Kaakinen, J. Kettunen, M.E. Kleber, X. Li, J. Luan, L.P. Lyytikäinen, P.K.E. Magnusson, M. Mangino, E. Mihailov, M.E. Montasser, M. Müller-Nurasyid, I.M. Nolte, J.R. O'Connell, C.D. Palmer, M. Perola, A.K. Petersen, S. Sanna, R. Saxena, S.K. Service, S. Shah, D. Shungin, C. Sidore, C. Song, R.J. Strawbridge, I. Surakka, T. Tanaka, T.M. Teslovich, G. Thorleifsson, E.G. Van den Herik, B.F. Voight, K.A. Volcik, L.L. Waite, A. Wong, Y. Wu, W. Zhang, D. Absher, G. Asiki, I. Barroso, L.F. Been, J.L. Bolton, L.L. Bonnycastle, P. Brambilla, M.S. Burnett, G. Cesana, M. Dimitriou, A.S.F. Doney, A. Döring, P. Elliott, S.E. Epstein, G. Ingi Eyjolfsson, B. Gigante, M.O. Goodarzi, H. Grallert, M.L. Gravito, C.J. Groves, G. Hallmans, A.-L. Hartikainen, C. Hayward, D. Hernandez, A.A. Hicks, H. Holm, Y.-J. Hung, T. Illig, M.R. Jones, P. Kaleebu, J.J.P. Kastelein, K.-T. Khaw, E. Kim, N. Klopp, P. Komulainen, M. Kumari, C. Langenberg, T. Lehtimäki, S.-Y. Lin, J. Lindström, R.J.F. Loos, F. Mach, W.L. McArdle, C. Meisinger, B.D. Mitchell, G. Müller, R. Nagaraja, N. Narisu, T.V.M. Nieminen, R.N. Nsubuga, I. Olafsson, K.K. Ong, A. Palotie, T. Papamarkou, C. Pomilla, A. Pouta, D.J. Rader, M.P. Reilly, P.M. Ridker, F. Rivadeneira, I. Rudan, A. Ruokonen, N. Samani, H. Scharnagl, J. Seeley, K. Silander, A. Stančáková, K. Stirrups, A.J. Swift, L. Tiret, A.G. Uitterlinden, L.J. van Pelt, S. Vedantam, N. Wainwright, C. Wijmenga, S.H. Wild, G. Willemsen, T. Wilsgaard, J.F. Wilson, E.H. Young, J.H. Zhao, L.S. Adair, D. Arveiler, T.L. Assimes, S. Bandinelli, F. Bennett, M. Bochud, B.O. Boehm, D.I. Boomsma, I.B. Borecki, S.R. Bornstein, P. Bovet, M. Burnier, H. Campbell, A. Chakravarti, J.C. Chambers, Y.-D.I. Chen, F.S. Collins, R.S. Cooper, J. Danesh, G. Dedoussis, U. de Faire, A.B. Feranil, J. Ferrières, L. Ferrucci, N.B. Freimer, C. Gieger, L.C. Groop, V. Gudnason, U. Gyllensten, A. Hamsten, T.B. Harris, A. Hingorani, J.N. Hirschhorn, A. Hofman, G.K. Hovingh, C.A. Hsiung, S.E. Humphries, S.C. Hunt, K. Hveem, C. Iribarren, M.-R. Järvelin, A. Jula, M. Kähönen, J. Kaprio, A. Kesäniemi, M. Kivimaki, J.S. Kooner, P.J. Koudstaal, R.M. Krauss, D. Kuh, J. Kuusisto, K.O. Kyvik, M. Laakso, T.A. Lakka, L. Lind, C.M. Lindgren, N.G. Martin, W. März, M.I. McCarthy, C.A. McKenzie, P. Meneton, A. Metspalu, L. Moilanen, A.D. Morris, P.B. Munroe, I. Njølstad, N.L. Pedersen, C. Power, P.P. Pramstaller, J.F. Price, B.M. Psaty, T. Quertermous, R. Rauramaa, D. Saleheen, V. Salomaa, D.K. Sanghera, J. Saramies, P.E.H. Schwarz, W.H.-H. Sheu, A.R. Shuldiner, A. Siegbahn, T.D. Spector, K. Stefansson, D.P. Strachan, B.O. Tayo, E. Tremoli, J. Tuomilehto, M. Uusitupa, C.M. van Duijn, P. Vollenweider, L. Wallentin, N.J. Wareham, J.B. Whitfield, B.H.R. Wolffenbuttel, J.M. Ordovas, E. Boerwinkle, C.N.A. Palmer, U. Thorsteinsdottir, D.I. Chasman, J.I. Rotter, P.W. Franks, S. Ripatti, L.A. Cupples, M.S. Sandhu, S.S. Rich, M. Boehnke, P. Deloukas, S. Kathiresan, K.L. Mohlke, E. Ingelsson, G.R. Abecasis, Global Lipids Genetics Consortium, Discovery and refinement of loci associated with lipid levels, Nat. Genet. 45 (2013) 1274-1283, https://doi.org/10.1038/ng.2797.

[29] A.R. Bentley, Y.J. Sung, M.R. Brown, T.W. Winkler, A.T. Kraja, I. Ntalla, K. Schwander, D.I. Chasman, E. Lim, X. Deng, X. Guo, J. Liu, Y. Lu, C.-Y. Cheng, X. Sim, D. Vojinovic, J.E. Huffman, S.K. Musani, C. Li, M.F. Feitosa, M.A. Richard, R. Noordam, J. Baker, G. Chen, H. Aschard, T.M. Bartz, J. Ding, R. Dorajoo, A.K. Manning, T. Rankinen, A.V. Smith, S.M. Tajuddin, W. Zhao, M. Graff, M. Alver, M. Boissel, J.F. Chai, X. Chen, J. Divers, E. Evangelou, C. Gao, A. Goel, Y. Hagemeijer, S.E. Harris, F.P. Hartwig, M. He, A.R.V.R. Horimoto, F.-C. Hsu, Y.J. Hung, A.U. Jackson, A. Kasturiratne, P. Komulainen, B. Kühnel, K. Leander, K.H. Lin, J. Luan, L.-P. Lyytikäinen, N. Matoba, I.M. Nolte, M. Pietzner, B. Prins, M. Riaz, A. Robino, M.A. Said, N. Schupf, R.A. Scott, T. Sofer, A. Stancáková, F. Takeuchi, B.O. Tayo, P.J. van der Most, T.V. Varga, T.-D. Wang, Y. Wang, E.B. Ware, W. Wen, Y.-B. Xiang, L.R. Yanek, W. Zhang, J.H. Zhao, A. Adeyemo, S. Afaq, N. Amin, M. Amini, D.E. Arking, Z. Arzumanyan, T. Aung, C. Ballantyne, R.G. Barr, L.F. Bielak, E. Boerwinkle, E.P. Bottinger, U. Broeckel, M. Brown, B.E. Cade, A. Campbell, M. Canouil, S. Charumathi, Y.-D.I. Chen, K. Christensen, COGENT-Kidney Consortium, M.P. Concas, J.M. Connell, L. de Las Fuentes, H.J. de Silva, P.S. de Vries, A. Doumatey, Q. Duan, C.B. Eaton, R.N. Eppinga, J.D. Faul, J.S. Floyd, N.G. Forouhi, T. Forrester, Y. Friedlander, I. Gandin, H. Gao, M. Ghanbari, S.A. Gharib, B. Gigante, F. Giulianini, H.J. Grabe, C.C. Gu, T.B. Harris, S. Heikkinen, C.-K. Heng, M. Hirata, J.E. Hixson, M.A. Ikram, EPIC-InterAct Consortium, Y. Jia, R. Joehanes, C. Johnson, J.B. Jonas, A.E. Justice, T. Katsuya, C.C. Khor, T.O. Kilpeläinen, W.-P. Koh, I. Kolcic, C. Kooperberg, J.E. Krieger, S.B. Kritchevsky, M. Kubo, J. Kuusisto, T.A. Lakka, C.D. Langefeld, C. Langenberg, L.J. Launer, B. Lehne, C.E. Lewis, Y. Li, J. Liang, S. Lin, C.-T. Liu, J. Liu, K. Liu, M. Loh, K.K. Lohman, T. Louie, A. Luzzi, R. Mägi, A. Mahajan, A.W. Manichaikul, C.A. McKenzie, T. Meitinger, A. Metspalu, Y. Milaneschi, L. Milani, K.L. Mohlke, Y. Momozawa, A.P. Morris, A.D. Murray, M.A. Nalls, M. Nauck, C.P. Nelson, K.E. North, J.R. O'Connell, N.D. Palmer, G.J. Papanicolau, N.L. Pedersen, A. Peters, P.A. Peyser, O. Polasek, N. Poulter, O.T. Raitakari, A.P. Reiner, F. Renström, T.K. Rice, S.S. Rich, J.G. Robinson, L.M. Rose, F.R. Rosendaal, I. Rudan, C.O. Schmidt, P.J. Schreiner, W.R. Scott, P. Sever, Y. Shi, S. Sidney, M. Sims, J.A. Smith, H. Snieder, J.M. Starr, K. Strauch, H.M. Stringham, N.Y.Q. Tan, H. Tang, K.D. Taylor, Y.Y. Teo, Y.C. Tham, H. Tiemeier, S.T. Turner, A.G. Uitterlinden, Understanding Society Scientific Group, D. van Heemst, M. Waldenberger, H. Wang, L. Wang, L. Wang, W.B. Wei, C.A. Williams, G. Wilson, M.K. Wojczynski, J. Yao, K. Young, C. Yu, J.-M. Yuan, J. Zhou, A.B. Zonderman, D.M. Becker, M. Boehnke, D.W. Bowden, J.C. Chambers, R.S. Cooper, U. de Faire, I.J. Deary, P. Elliott, T. Esko, M. Farrall, P.W. Franks, B.I. Freedman, P. Froguel, P. Gasparini, C. Gieger, B.L. Horta, J.-M.J. Juang, Y. Kamatani, C.M. Kammerer, N. Kato, J.S. Kooner, M. Laakso, C.C. Laurie, I.-T. Lee, T. Lehtimäki, Lifelines Cohort, 
P.K.E. Magnusson, A.J. Oldehinkel, B.W.J.H. Penninx, A.C. Pereira, R. Rauramaa S. Redline, N.J. Samani, J. Scott, X.-O. Shu, P. van der Harst, L.E. Wagenknecht, J.S. Wang, Y.X. Wang, N.J. Wareham, H. Watkins, D.R. Weir, A.R. Wickremasinghe, T. Wu, E. Zeggini, W. Zheng, C. Bouchard, M.K. Evans, V. Gudnason, S.L.R. Kardia, Y. Liu, B.M. Psaty, P.M. Ridker, R.M. van Dam, D.O. Mook-Kanamori, M. Fornage, M.A. Province, T.N. Kelly, E.R. Fox, C. Hayward, C.M. van Duijn, E.S. Tai, T.Y. Wong, R.J.F. Loos, N. Franceschini, J.I. Rotter, X. Zhu, L.J. Bierut, W.J. Gauderman, K. Rice, P.B. Munroe, A.C. Morrison, D.C. Rao, C.N. Rotimi, L.A. Cupples, Multi-ancestry genome-wide gene-smoking interaction study of 387,272 individuals identifies new loci associated with serum lipids, Nat. Genet. 51 (2019) 636-648, https://doi.org/10.1038/s41588-019-0378-y.

[30] K. Bandesh, G. Prasad, A.K. Giri, Y. Kauser, M. Upadhyay, INDICO, A. Basu, N. Tandon, D. Bharadwaj, Genome-wide association study of blood lipids in Indians confirms universality of established variants, J. Hum. Genet. 64 (2019) 573-587, https://doi.org/10.1038/s10038-019-0591-7.

[31] H.-C. Fung, S. Scholz, M. Matarin, J. Simón-Sánchez, D. Hernandez, A. Britton, J.R. Gibbs, C. Langefeld, M.L. Stiegert, J. Schymick, M.S. Okun, R.J. Mandel, H.H. Fernandez, K.D. Foote, R.L. Rodríguez, E. Peckham, F.W. De Vrieze, K. GwinnHardy, J.A. Hardy, A. Singleton, Genome-wide genotyping in Parkinson's disease and neurologically normal controls: first stage analysis and public release of data, Lancet Neurol. 5 (2006) 911-916, https://doi.org/10.1016/S1474-4422(06) 70578-6.

[32] M. Futema, V. Plagnol, K. Li, R.A. Whittall, H.A.W. Neil, M. Seed, Simon Broome Consortium, S. Bertolini, S. Calandra, O.S. Descamps, C.A. GCraham, R.A. Hegele, F. Karpe, R. Durst, E. Leitersdorf, N. Lench, D.R. Nair, H. Soran, F.M. Van Bockxmeer, UK10K Consortium, S.E. Humphries, Whole exome sequencing of familial hypercholesterolaemia patients negative for LDLR/APOB/PCSK9 mutations,
J. Med. Genet. 51 (2014) 537-544, https://doi.org/10.1136/jmedgenet-2014102405.

[33] I. Brænne, B. Reiz, A. Medack, M. Kleinecke, M. Fischer, S. Tuna, C. Hengstenberg, P. Deloukas, J. Erdmann, H. Schunkert, Cardiogenics consortium, Whole-exome sequencing in an extended family with myocardial infarction unmasks familial hypercholesterolemia, BMC Cardiovasc. Disord. 14 (2014) 108, https://doi.org/10. 1186/1471-2261-14-108.

[34] S.M. Han, B. Hwang, T. Park, D.-I. Kim, M.-Y. Rhee, B.-K. Lee, Y.K. Ahn, B.R. Cho, J. Woo, S.-H. Hur, J.-O. Jeong, S. Park, Y. Jang, M.G. Lee, D. Bang, J.H. Lee, S.$\mathrm{H}$. Lee, Genetic testing of Korean familial hypercholesterolemia using whole-exome sequencing, PLoS One 10 (2015) e0126706, https://doi.org/10.1371/journal.pone. 0126706.

[35] L. Jiang, W.-F. Wu, L.-Y. Sun, P.-P. Chen, W. Wang, A. Benito-Vicente, F. Zhang, X.D. Pan, W. Cui, S.-W. Yang, Y.-J. Zhou, C. Martin, L.-Y. Wang, The use of targeted exome sequencing in genetic diagnosis of young patients with severe hypercholesterolemia, Sci. Rep. 6 (2016) 36823, https://doi.org/10.1038/srep36823.

[36] M.A. Iacocca, J. Wang, S. Sarkar, J.S. Dron, T. Lagace, A.D. McIntyre, P. Lau, J.F. Robinson, P. Yang, J.H. Knoll, H. Cao, R. McPherson, R.A. Hegele, Whole-gene duplication of PCSK9 as a novel genetic mechanism for severe familial hypercholesterolemia, Can. J. Cardiol. 34 (2018) 1316-1324, https://doi.org/10.1016/j. cjca.2018.07.479.

[37] I. Lamiquiz-Moneo, M.R. Pérez-Ruiz, E. Jarauta, M.T. Tejedor, A.M. Bea, R. MateoGallego, S. Pérez-Calahorra, L. Baila-Rueda, V. Marco-Benedí, I. de Castro-Orós, A. Cenarro, F. Civeira, Single nucleotide variants associated with polygenic hypercholesterolemia in families diagnosed clinically with familial hypercholesterolemia, Rev. Esp. Cardiol. 71 (2018) 351-356, https://doi.org/10.1016/j.rec.2017. 07.010. 